\title{
Highly conserved karyotypes of Systenocentrus japonicus and Paraumbogrella pumilio (Opiliones: Sclerosomatidae: Gagrellinae) supporting their close relationship
}

\author{
Nobuo Tsurusaki* \& Satoshi Kawato \\ Laboratory of Biology, Faculty of Regional Sciences, Tottori University, Tottori, 680-8551 Japan \\ *E-mail: ntsuru@rs.tottori-u.ac.jp
}

\begin{abstract}
Karyotypes of two sclerosomatid harvestmen, Systenocentrus japonicus and Paraumbogrella pumilio, were analyzed. Males of the both species shared a very similar karyotype with $2 n=10$ comprised of four metacentric pairs of autosomes and a submetacentric X and a metacentric $\mathrm{Y}$ chromosome. The karyotype was conservative also within each species. Sharing of the conserved karyotype supports close relationship of the two species, which is also suggested by several other morphological and ecological characteristics. Distribution maps of the two species are provided.
\end{abstract}

Key words - karyotypes, chromosomes, Systenocentrus japonicus, Paraumbogrella pumilio, Gagrellinae

\section{Introduction}

Systenocentrus japonicus Hirst 1911 (Sclerosomatidae: Gagrellinae) is a soil-dwelling species of harvestman that occurs in three main islands (Honshu, Shikoku, and Kyushu) of Japan (Suzuki \& Tsurusaki 1981) (Fig. 1, below). This species is relatively small (body length ca. $2.5-3.0 \mathrm{~mm}$ in males, ca. $4.0 \mathrm{~mm}$ in gravid females) compared to most other species of Sclerosomatidae (usually 5$11 \mathrm{~mm}$ in both males and none-gravid females). Beside the body size, it is easily identified by having five or six long dorsal spines longitudinally arranged on the posterior part of the body. There is $0^{-} 1$ spine on the 2 nd thoracic tergite (see below for more information) and one spine on each 1st to 5th abdominal tergites (Suzuki \& Tsurusaki 1981). On the other hand, this species shows close similarities in various characters to another small-sized species of Gagrellinae, Paraumbogrella pumilio (Karsch 1881) (=Paraumborella huzitai Suzuki 1963: see Suzuki 1985 for the synonymy), which is distributed in the central and northeastern part of Honshu and Hokkaido (Fig. 1, above), though absence of long dorsal spines on the body in $P$. pumilio gives a general appearance completely different from $S$. japonicus. Characters only shared by the both species (at least in all of the Japanese species of Gagrellinae) include: 1) small size of the body with relatively short legs (the 1st and 3rd femora shorter than body); 2) sclerotized integument of the body covered with coarse granules; 3 ) stumpy palp whose femur with a medial row of large teeth on basal two-thirds (cf. fig. 3B-C in Suzuki 1963 for P. pumilio and figs. 2C-E in Suzuki \& Tsurusaki 1981 for S. japonicus); 4) short dorsoventrally flattened penis with well-developed lateral wings (cf. fig. 3H in Suzuki 1963 and fig. 11H-I in Suzuki \& Tsurusaki 1983 for $P$. pumilio vs. figs. $2 \mathrm{G}^{-} \mathrm{J}$ in Suzuki \& Tsurusaki 1981 for S. japonicus); 5) a similar pattern of the univoltine life cycle with adult overwintering (Tsurusaki 2003 for P. pumilio and Suzuki \& Tsurusaki 1981 for $S$. japonicus) (adult overwintering has been known only in these two species among ca. 40 species of Sclerosomatidae in Japan).

The diploid chromosome number (2n) reported for the two species also evokes a close relationship of the two species. The $2 \mathrm{n}$ reported with karyological information for the two different populations (Sapporo and Sunagawa) in Hokkaido of $P$. pumilio is $2 \mathrm{n}=10$ (Tsurusaki 1982, Tsurusaki \& Cokendolpher 1990), which is the lowest chromosome number in harvestmen (Tsurusaki 2007a). Additionally, Suzuki (1966) briefly mentioned the haploid chromosome number (n) of $S$. japonicus as $\mathrm{n}=5$ in his review of biology of harvestmen (p. 113 in Suzuki 1966), although unfortunately no detailed data (photos, karyotypes, locality which the material examined was collected from, etc.) were published. The diploid chromosome number of eight species of Gagrellinae so far reported, of these, six species belong to the Asian Gagrellinae clade and the remaining two to the New World Gagrellinae clade; both the clades are not closely ralated (Hedin et al. 2012) varies from 10 to 22 , with $2 \mathrm{n}=16$ and 18 as the mean and the median, respectively (Tsurusaki \& Cokendolpher 1990, Tsurusaki 2007a, Rodríguez Gil \& Mola 2010). It seems that $2 \mathrm{n}=10$, which is represented only by $S$. japonicus, $P$. pumilio, and a few populations of Gagrellula ferruginea in the Asian Gagrellinae clade, deviates appreciably from the mean $(2 \mathrm{n}=16)$ and median $(2 \mathrm{n}=18)$. 

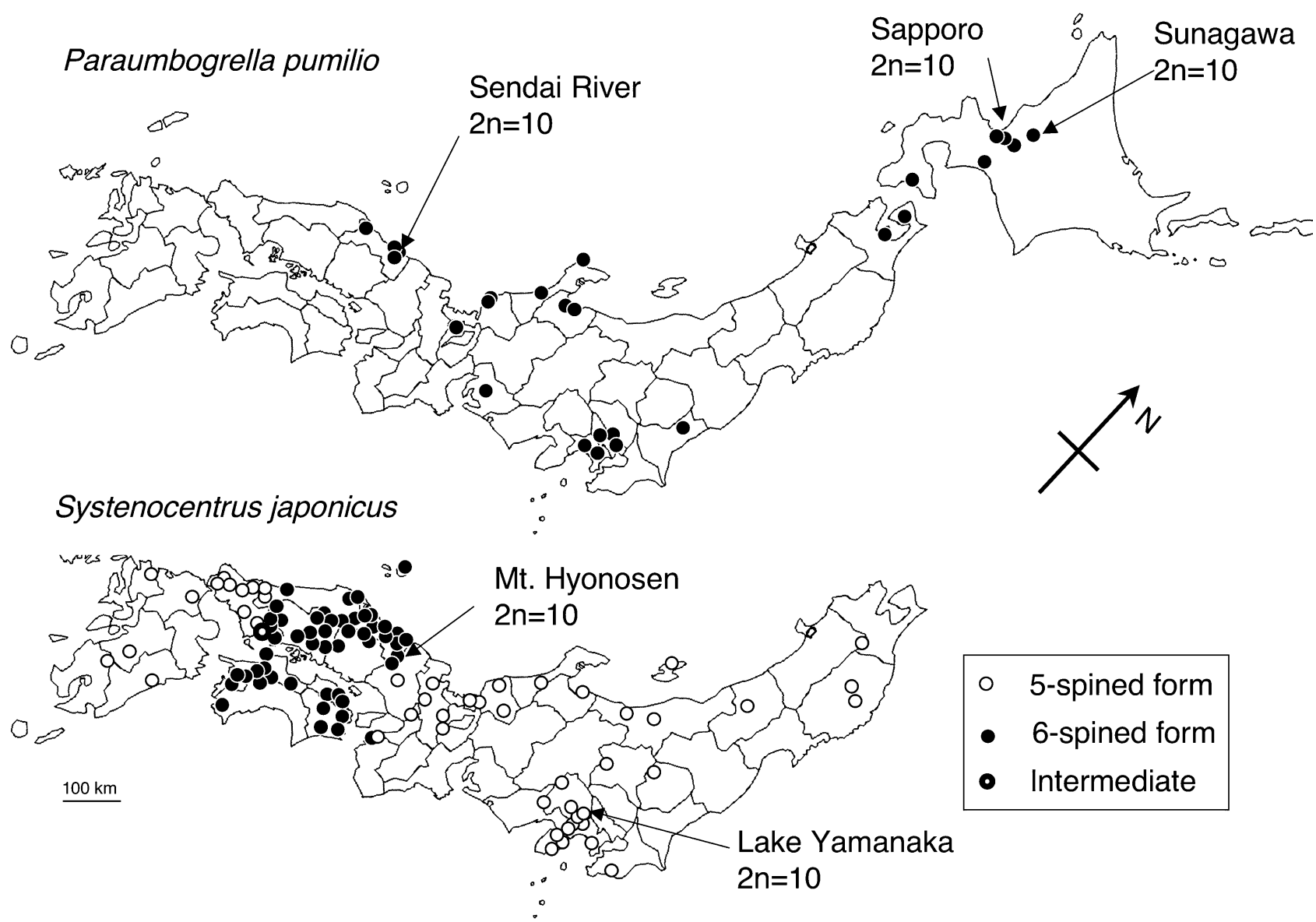

Fig. 1. Distribution of Paraumbogrella pumilio (above) and Systenocentrus japonicus (below). Localities, where chromosomes were studied from, are shown. The distribution maps were compiled based on literature records and data from unpublished specimens (unpublished records are listed in the Appendix). The diploid chromosome numbers of Sapporo and Sunagawa populations of $P$. pumilio are adopted from Tsurusaki (1982) and Tsurusaki \& Cokendolpher (1990), respectively.

However, chromosome numbers are highly variable in various groups of harvestmen including Gagrellinae and the same chromosome numbers frequently evolved via random mutations and random fixation within each population. Thus, information about the karyotypes of $S$. japonicus is indispensable to infer close affinity of $S$. japonicus and $P$. pumilio.

The purpose of the present study was to examine the karyotype of Systenocentrus japonicus in comparison with that of Paraumbogrella pumilio, to confirm their $2 \mathrm{n}$, and to provide their geographical distribution in Japan.

\section{Materials and methods}

The karyological data were obtained from testes or ovaries of field-collected adults by air-drying method with dissociation process using lactic acid (Tsurusaki 2007b). Chromosomes were observed using an Olympus BX60 microscope and photographed with an Olympus DP25 camera. Digital images of chromosomes were measured for photographs with a digital caliper and idiograms were constructed using the drawing software DeltaGraph (version 5.5.5) loading calculated values of relative lengths of all the chromosome arms on the Microsoft Excel spreadsheet. Nomenclature of chromosomes follows Levan et al. (1964): metacentric $(1.0 \leqq r<1.67)$, submetacentric $(1.67 \leqq r<3.0)$, subtelocentric $(3.0 \leqq r<7.0)$, acrocentric $(7.0 \leqq r<\infty)$, and telocentric $(r=\infty) . \quad r=\mathrm{L} / \mathrm{S}$, where $\mathrm{L}$ and $\mathrm{S}$ are lengths of long arm and short arm, respectively. The format of description of karyotypes follows Tsurusaki \& Cokendolpher (1990). Idiograms were made based on percentage ratios of each component chromosome to the total length of all haploid autosomes and an X chromosome (the so called total chromosome length, TCL).

Materials used are listed in Table 1.

Systenocentrus japonicus. In this species, two geographical forms which differ in the number of dorsal spines one another have been recognized: the five-spined form that is distributed in the eastern part and westernmost part (Yamaguchi Pref.) of Honshu and Kyushu and the sixspined form that occurs in the Chugoku District of Honshu except for Yamaguchi Pref., and Shikoku (Suzuki \& Tsurusaki 1981) (Fig. 1, below). Chromosomes were examined for the following two populations each of which represents one of the two geographical forms. 
Table 1. A list of specimens of Systenocentrus japonicus and Paraumbogrella pumilio used in the present study and results obtained with known literatrure data.

\begin{tabular}{|c|c|c|c|c|c|}
\hline Species & Locality & Date collected & No. indiv. & $\begin{array}{l}\text { Number of } \\
\text { chromosomes } \\
(2 \mathrm{n})\end{array}$ & References \\
\hline \multirow[t]{3}{*}{ S. japonicus } & Lake Yamanaka, Yamanashi Pref., Honshu & 21 Sept. 1995 & 1 1 1 우 & $10 /-$ & Present study \\
\hline & Mt. Hyonosen, Tottori Pref., Honshu & 12 Sept. 2012 & $23^{\pi}$ & 10 & Present study \\
\hline & Locality unknown & 一 & $10^{\star} ?$ & 10 & Suzuki 1966 \\
\hline \multirow[t]{3}{*}{ P. pumilio } & Sunagawa, Hokkaido & - & $10^{\pi}$ & 10 & $\begin{array}{l}\text { Tsurusaki \& } \\
\text { Cokendolpher } 1990\end{array}$ \\
\hline & $\begin{array}{l}\text { Campus of Hokkaido Univ., Sapporo, } \\
\text { Hokkaido (sub P. huzitai) }\end{array}$ & - & $2 \delta^{\pi} / 2$ 우 & $10 / 10$ & Tsurusaki 1982 \\
\hline & Sendai Ôhashi Bridge, Tottori City, Honshu & 12 Oct. 2012 & $20^{\pi}$ & 10 & Present study \\
\hline
\end{tabular}
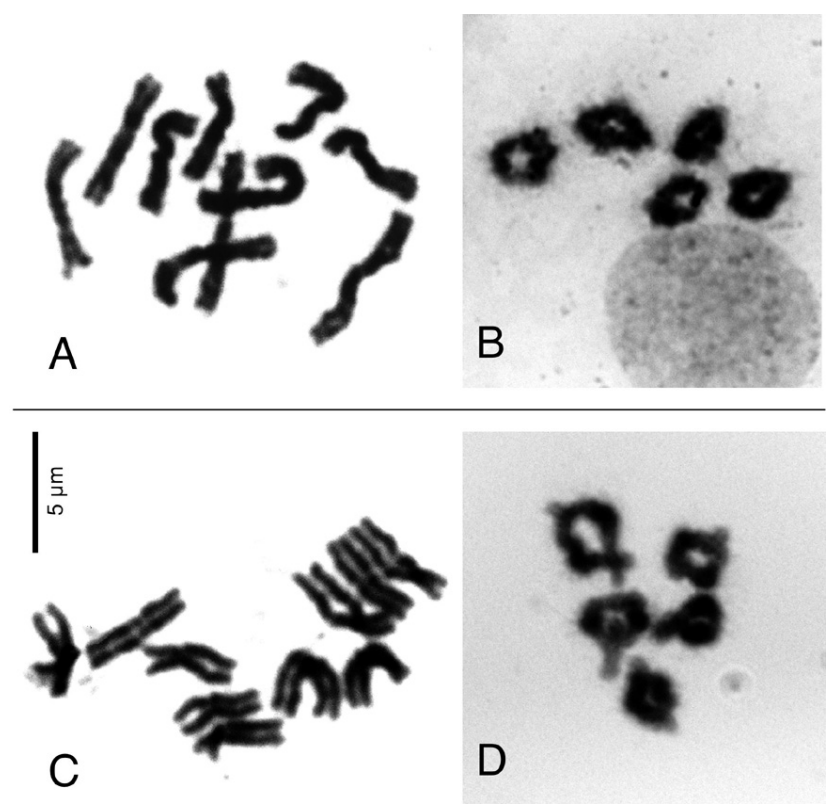

Fig. 2. Spermatogonical metaphase plates with $2 n=10$ (left) and the first meiotic metaphase (MI) with $2 \mathrm{n}=10$ (right). A-B, Systenocentrus japonicus (The six-spined form), Mt. Hyonosen, a male; C-D, Paraumbogrella pumilio, Sendai River, Tottori City a male. Scale bar $5 \mu \mathrm{m}$.

Six-spined form: 2 males, Mt. Hyonosen, $820 \mathrm{~m}$ alt., Wakasa-cho, Tottori Pref., Honshu, 12 September 2012.

Five-spined form: 1 male and 1 female; Mama-no-mori Forest, Fudôzaka, $1010 \mathrm{~m}$ alt., Lake Yamanaka, Yamanakako-mura, Minami-tsuru-gun, Yamanashi Pref., Honshu, 21 September 1995.

Paraumbogrella pumilio. 1 male, Flood channel of Sendai River, just upper stream side of the Sendai-ôhashi Bridge, Furumi, Tottori City, Tottori Pref., Honshu, 24 October 2012.

\section{Results}

Systenocentrus japonicus, the six-spined form from Mt. Hyonosen: $2 \mathrm{n}=10$ (Figs. 2A-B, 3A). A total of 13 wellspread spermatogonial metaphase plates and numerous first and second meiotic metaphase plates showed $2 \mathrm{n}=10$ (Fig. 2A) and $n=5$ (Fig. 2B), respectively. The karyotype obtained consisted of four pairs of metacentric autosomes and a heteromorphic pair of chromosomes that are considered to be the sex chromosomes. Of the heteromorphic pair, the larger submetacentric and the slightly smaller metacentric chromosomes were considered to be $\mathrm{X}$ and $\mathrm{Y}$, respectively, because $\mathrm{X}$ chromosomes are always larger than $\mathrm{Y}$ chromosomes in all animals including harvestmen with male heterogametic XY-XX system of sex determination (Figs. $2 \mathrm{~A}, 3 \mathrm{~A})$. Length of the $\mathrm{X}$ chromosome was approximately the same (relative length to TCL: $16.1 \%$ ) as that of the 4th pair of autosomes (17.1\%) (Fig. 3A).

Systenocentrus japonicus, the five-spined form from Lake Yamanaka: $2 n=10$. The diploid chromosome number was determined on the basis of a total of 14 male spermatogonial metaphase spreads, though no countable chromosomal spreads were obtained from the female prepared. There was no significant difference in karyotypes between males of the 6-spined form from Mt. Hyonosen and the 5-spined form from Lake Yamanaka.

The first meiotic metaphases abundantly obtained for the males from both populations showed five ring-shaped bivalents (i.e. two terminal chiasmata per bivalent. Fig. 2B) or four ring-shaped + one rod-shaped bivalents. This means that $\mathrm{X}$ and $\mathrm{Y}$ chromosomes pair during prophase and metaphase in the first meiotic division, though we failed to identify a bivalent representing the $\mathrm{X}-\mathrm{Y}$ association.

Paraumbogrella pumilio, Sendai-ohashi Bridge population, Tottori, Figs. $2 \mathrm{C}-\mathrm{D}, 3 \mathrm{~B}: 2 \mathrm{n}=10$. A total of 17 wellspread spermatogonial metaphase plates were available from the both males examined. The karyotype obtained for males was almost completely the same as that of the former species, namely, it was composed of four metacentric pairs of autosomes and a submetacentric $\mathrm{X}$ and a metacentric $\mathrm{Y}$ chromosome (Figs. 2C, 3B).

The first meiotic metaphases abundantly observed showed $\mathrm{n}=5$, with five or four ring-shaped bivalents (Fig. 2D). Sex chromosome bivalents were not discernible from the remaining bivalents.

\section{Discussion}

One of the distinct features of chromosomal evolution in harvestmen is high variability of the chromosome number found in several species or species-groups such as Gagrellopsis nodulifera Sato \& Suzuki 1939 (formerly 

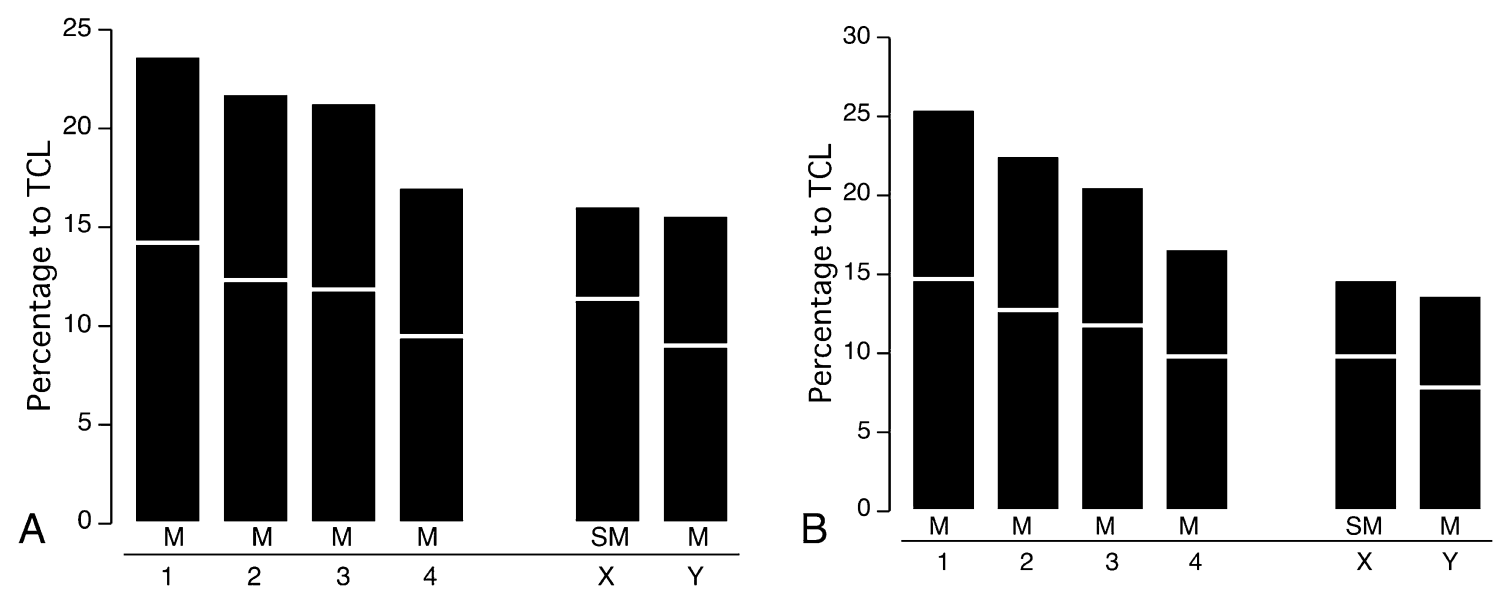

Fig. 3. Idiograms of karyotypes based on figures shown in Fig. 2A and C. A, Systenocentrus japonicus (The six-spined form), Mt. Hyonosen, a male; B, Paraumbogrella pumilio, Sendai River, Tottori City, a male. $\mathrm{M}=$ metacentric, $\mathrm{SM}=\mathrm{submetacentric}$. TCL $=$ total chromosome length (total lengths of haploid autosomes + an $\mathrm{X}$ chromosome).

Gagrellinae; the G. nodulifera + the Leiobunum curvipalpe-group clade in Hedin et al. 2012), Gagrellula ferruginea (Loman 1902) (Gagrellinae), the Leiobunum curvipalpe-group etc. (Tsurusaki 2007a). However this variability is not the norm among harvestmen and there are also several species whose diploid chromosome number is quite constant through the wide range of the species distribution, such as Melanopa grandis Roewer 1910 (Gagrellinae) or Leiobunum japonicum Müller 1914 (this species is not of Leiobuninae but a close relative of Asian Gagrellinae: Hedin et al. 2012), both of which invariably show $2 \mathrm{n}=20$. We might be able to add Systenocentrus japonicus and Paraumbogrella pumilio to the list because there was no intraspecific variation in the karyotypes, though the numbers of populations examined are still few (only two in S. japonicus and only three in P. pumilio: Tsurusaki 1982, Tsurusaki \& Cokendolpher 1990).

The present study also revealed that there was no significant difference between the karyotypes of $P$. pumilio and those of Systenocentrus japonicus. Furthermore, the configuration of bivalents in the first meiotic division, which is dominated by bivalents with two terminal chiasmata (Fig. 2B, D, also see fig. 1e in P. pumilio in Tsurusaki 1982), also looks very similar between the two species. Usually, bivalents with two chiasmata are fewer than those with one terminal or subterminal chiasma as it was reported in meiosis of harvestmen (ك̌t'áhlavský et al. 2012). Thus, it is difficult to envisage that these karyological similarities evolved as convergence in two different lineages. It is likely that the karyological similarity, therefore, safely supports close phylogenetic relationship of the two species.

The genus Systenocentrus includes six species from India, Myanmar, Thailand, China, and Japan (Roewer 1955; Suzuki 1982). However, it seems that diagnostic characters that can be used to unite these six species are rather poor, although they share a 5-spined abdominal scutum that characterize the genus. On the other hand, there are two species that are now placed in other genera but show close affinity in various characters to Systenocentrus japonicus. One is Hamitergum eobius (Redikorzew 1936), the single species of the monotypic genus Hamitergum Crawford 1992 (replaced name for Lophacanthus Redikorzev 1936: Crawford 1992), from Far East Russia and Korea. Hamitergum eobius has a body with six dorsal spines, each on 1st to 6th abdominal tergites (Redikorzev 1936, Staręga 1965, Gritzenko 1979). However, except for the presence of the spine on the 6th tergite, the species cannot be distinguished from the five-spined form of Systenocentrus japonicus. Thus, it is highly probable that $H$. eobius and $S$. japonicus are nothing more than two vicarious species of a single superspecies or two subspecies (or geographical races) of a single species. The other is Paraumbogrella pumilio, again the single species of the monotype genus Paraumbogrella Suzuki 1963 (Suzuki 1963, 1985).

As already mentioned, beside the karyotype, $P$. pumilio and $S$. japonicus retain many morphological and ecological characters in common. All the characters 1-5 listed in the Introduction are also shared by Hamitergum eobius but not shared by most other species of Gagrellinae including at least some species of genus Systenocentrus. For example, most other species of Systenocentrus are much larger (body length reaches ca. $7-8 \mathrm{~mm}$ ) than $S$. japonicus (plus $H$. eobius and P. pumilio) and the palp of Systenocentrus biseriatus Suzuki 1982 from Thailand lacks a longitudinal row of large teeth on medial surface of the femur (Suzuki 1982). These situations should be taken into consideration when re-examination of the phylogeny and classification of the two species plus Hamitergum eobius and other species of Systenocentrus are made in the future.

\section{Acknowledgments}

The present study was partly supported by JSPS KAKENHI Grant Numbers 06640901 and 22570092 to NT. We are grateful to the two anonymous referees for their valuable comments and suggestion. We 
thank also following people who provided specimens of $S$. japonicus and $P$. pumilio at NT's disposal: Jun-ichi Aoki, Shizuo Fujiyama, Yasutaka Fujita, Yoshimasa Goto, Masakazu Hayashi, Toshio Hayashi, late Yoshiko Hirauchi, Hiroyoshi Ikeda, Masami Imai, Teruo Irie, Kiyoshi Ishii, Keisuke Kawano, Maki Koishi, Nao Matsumoto, Toshihiko Matsuo, Susumu Mitani, Yoshiaki Nishikawa, Susumu Nakano, Noboru Nunomura, Ryoichi Ohgushi, Masahisa Ohrui, Mari Oonishi, late Hiroyuki Sasaji, Hiroshi Saito, Tsutomu Tanabe, Keiko Ueno, Eiji Yamamoto, Nobuyo Yoshida.

\section{References}

Crawford, R. L. 1992. Catalogue of the genera and type species of the harvestman superfamily Phalangioidea (Arachnida). Burke Mus. Contribut. Anthropol. \& Nat. Hist., No. 8, pp. 1-60.

Gritzenko, N. I. 1979. Materials on the Opiliones fauna from Primorye region. In: Ler, P. A. (ed.), Terrestrial Arthropoda of the Far East. Academia Nauk SSSR, Vladivostok, 148 pp. (In Russian)

Hedin, M., Tsurusaki, N., Macías-Ordôñez, R., \& Shultz, J. W. 2012. Molecular systematics of sclerosomatid harvestmen (Opiliones, Phalangioidea, Sclerosomatidae): geography is better than taxonomy in predicting phylogeny. Mol. Phyl. Evol., 62: 224-236.

Levan, A., Fredga, K. \& Sandberg, A. A. 1964. Nomenclature for centric position on chromosomes. Hereditas (Lund), 52: 201-220.

Redikorzev, V. 1936. Beiträge zur Opilioniden-Fauna von USSR. Trudy Zool. Insti. Acad. Nauk SSSR., 3: 33-57. (In Russian)

Rodriguez Gil, S. G. \& Mola, L. M. 2010. Chromosome complement and meiosis of Holmbergiana weyenberghii (Opiliones: Sclerosomatidae: Gagrellinae) from Argentina. Rev. Soc. Entomol. Argent., 69: 167-170.

Roewer, C. F. 1955. Indoaustralische Gagrellinae (Opiliones, Arachnidae). (Weitere Weberknechte XVIII) 3 Teil. Senckenbergiana Biol., 36: 71-121.

Št'áhlavský, F., Boyer, S. L., Harvey, M. S. and Giribet, G. 2012. First cytogenetic study of a member of the harvestman family Pettalidae (Opiliones: Cyphophthalmi). Aust. J. Entomol., 51: 299302.

Staręga, W. 1965. Einige Weberknechte (Opiliones) aus Nordkorea. (Materialien zur Kenntnis der ostasiatischen Weberknechte, V). Ann. Zool., Warszawa, 23: 5-14.

Suzuki, S. 1963. A new genus of Gagrellinae (Opiliones) from Japan. Annot. Zool. Japon., 36: 97-101.

Suzuki, S. 1966. Opiliones. Pp. 90-139. In: T. Uchida (ed.) Dobutsu Keitobunrui-gaku (=Systematic Zoology) Vol. 7(2A), Nakayamashoten Press, Tokyo, 307 pp. (In Japanese)

Suzuki, S. 1982. Four new harvestmen from Thailand (Arachnida, Opiliones, Gagrellidae). Annot. Zool. Japon., 55: 167-174.

Suzuki, S. 1985. Revision of five problematical species of Japanese Opiliones. Proc. Jpn. Soc. Syst. Zool., No. 30, pp. 53-59.

Suzuki, S. \& Tsurusaki, N. 1981. Redescription of Systenocentrus japonicus (Arachnida, Opiliones, Leiobunidae) with special reference to its two geographic forms. Annot. Zool. Japon., 54: 273-283.

Suzuki, S. \& Tsurusaki, N. 1983. Opilionid fauna of Hokkaido and its adjacent areas. J. Fac. Sci. Hokkaido Univ., (VI, Zool.), 23: 195243.

Tsurusaki, N. 1982. Chromosomes of the Japanese gagrellid, Paraumbogrella huzitai Suzuki (Gagrellidae, Opiliones, Arachnida). Bull. Br. Arachnol. Soc., 5: 397-398.

Tsurusaki, N. 2003. Phenology and biology of harvestmen in and near Sapporo, Hokkaido, Japan, with some taxonomical notes on Nelima suzukii n. sp. and allies (Arachnida: Opiliones). Acta Arachnol., 52: 5-24.

Tsurusaki, N. 2007a. Chapter 6. Cytogenetics. Pp. 266-279. In: Pinto da Rocha, R., Machad, G. \& Giribet, G. (eds.) The Harvestmen: The Biology of Opiliones. Harvard University Press, Cambridge, Massachusetts, $597 \mathrm{pp}$.

Tsurusaki, N. 2007b. Methods of chromosome preparation. Pp. 511516. In: Pinto da Rocha, R., Machad, G. \& Giribet, G. (eds.) The
Harvestmen: The Biology of Opiliones. Harvard University Press, Cambridge, Massachusetts, $597 \mathrm{pp}$.

Tsurusaki, N. \& Cokendolpher, J. C. 1990. Chromosomes of sixteen species of harvestmen (Arachnida, Opiliones, Caddidae and Phalangiidae). J. Arachnol., 18: 151-166.

Received July 21, 2013 / Accepted September 25, 2013

Appendix. Specimens used to draw distribution maps shown in Fig. 1.

Only specimens whose records have not been mentioned in the previous literature are listed here. Each record consists of: locality, altitude, number of specimens (juv. $=$ juveniles), date collected, collected by $(\mathrm{NT}=\mathrm{N}$. Tsurusaki). "Chrom" = specimens used for chromosome preparation.

Systenocentrus japonicus. Five-spined form - IWATE PREF.

Iwate-gun, Takizawa-mura, Naranokizawa, FSC Takizawa Experiment Forest of Iwate University, 1우, 19 September 2007, Yasutaka Fujita. Miyako City, Kawai-mura, Mt. Kabuto-Myôjin, Kuzakai, 900 m, 1우, 29 September 1984, NT. TOCHIGI PREF. Nikko, Senjôgahara, 1우, 16 October 2002, Maki Koishi. GUMMA PREF. - Mt. Myôgi, Myôgi Shrine, 460-500 m, 1 juv., 26 August 1982, NT. CHIBA PREF. - Kamogawa City, Mt. Kiyosumi, Seichô-ji Temple, 300-320 m, 1 juv., 27 August 1984, NT. KANAGAWA PREF. - Kamakura City, Mt. Ôhira, Cryptomeria japonica forest, $120 \mathrm{~m}, 1$ 우, 6 December 1989, NT. Isehara City, Mt. Ôyama, Shimosha, Cryptomeria japonica forest, 760 m, 1 juv., 25 August 1986, NT. Sagamihara City, Tsukui-machi, Mizusawa Forest Road (Tanzawa), 480 m, 1 juv., 28 August 1994, Yoshimasa Goto. Ashigara-kami-gun, Ôi-cho, Kami-Ôi, Mishima Shrine, 1ð`, 24 August 1992, Masahisa Ohrui. Ashigara-shimo-gun, Hakone-cho, Sengokubara: Kintoki Shrine, $850 \mathrm{~m}, 10^{\Uparrow}$, 15 September 1984, Masahisa Ohrui; Kojiri, Chamaecyparis obtusa forest, 790 m, 1ð2우, 8 October 1980, NT. Ashigara-shimo-gun, Hakone-cho, Ôhiradai, 12 우, 22 September 1986, Mika Kubodera \& Shigeyo Inaba. NIIGATA PREF. - Is. Sado, Mt. Myôken, Fagus crenata forest, 850-940 m, 2 ऽ’, 21 July 1980, NT. TOYAMA PREF. - Uozu City, Hirasawa, along Katagai River, 1ð2우, 23 September 1993, Noboru Nunomura. ISHIKAWA PREF. - Kanazawa City, Mt. Iô, Iô-no-sato Camping ground, Cryptomeria japonica forest, 510 m, 2 juv., 24 August 1994, NT. FUKUI PREF. - Sakai City, Maruoka-cho, Kawakami, Aotani, 2 juv., 2 August 1992, Hiroyuki Sasaji. Ohno City, Izumi-mura, China, Horadani, 2 juv., 1 August 1989, Hiroyuki Sasaji. MinamiEchizen-cho, Imajô-cho, Kokura Pass, 970 m, 1우, 2 November 1990 , NT. Tsuruga City, Mt. Nosaka, Cryptomeria japonica forest, $120 \mathrm{~m}$, 1 juv., 25 August 1994, NT. YAMANASHI PREF. - Hokuto City, Hakushu-machi, Oshirakawa Gorge, 2ᄌ2우, 24 September 1990, Hiroshi Saito. Minami-Tsuru-gun: Fuji-Kawaguchiko-machi (Kawaguchiko-machi), Asakawa, 1 juv., 1 August 1998, Masami Imai; Yamanakako-mura, Lake Yamanaka, Fudôzaka, Mama-no-mori Forest, $1010 \mathrm{~m}, 2 \jmath^{2} 2$ 우 (1 $\jmath^{\top} 1$ ㅇChrom), 21 September 1995, NT. Fujiyoshida City, Yoshidaguchi Starting Point for a Climb, 950 m, 1 juv., 22 August 1986, Shizuo Fujiyama. SHIZUOKA PREF. - Izu: Amagi Pass, 700 m, 1 juv., 20 August 1980, Masahisa Ohrui; Minamiizu, Shotsubo Pass, 1우, 3 September 1980, collector unknown. Shizuoka City, Umegashima Spa, 900-1050 m, 2 juv., 1 September 1981, NT. SHIGA PREF. - Otsu City, Ikadate-Tochu-cho, 1ð , 17 May 1993, Tsutomu Tanabe. KYOTO PREF. - Funai-gun, Kyotanba-cho (Mizuho-cho), Shizushi, Enoki Pass, Cryptomeria japonica forest, 360 m, 4 juv., 1 August 1991, NT. OSAKA PREF. Mino-o City, Mino-o Park, Sasagare-no-komichi, ca. $370 \mathrm{~m}, 1 \delta^{2} 2$ 우, 26-29 March 1977, Yoshiaki Nishikawa. HYOGO PREF. Kanzaki-gun, Kamikawa-cho (Ôkawachi-cho), Tonomine-kôgen highland, 550 m, 5우, 9-10 October 1976, Yoshiaki Nishikawa. 
SHIMANE PREF. - Kanoashi-gun, Tsuwano-cho: (Nichihara-cho), Aohara-Hachimangû Shrine, Cryptomeria japonica forest, $50 \mathrm{~m}, 2$ juv., 16 July 1988, NT; (Tsuwano-cho), Mt. Aono, Chamaecyparis obtusa forest, $410 \mathrm{~m}, 1$ juv., 20 July 1990, NT. YAMAGUCHI PREF. - Abu-gun, Abu-cho, Tsurugamine Hachiman-gu Shrine, 10 m, 1 juv., 20 July 1990, NT. Hagi City: Kawakami, Notoro, 1 우, 8 May 2012, Shin-ichi Tanaka; Asahi-mura, Shimo-Nagase, Cryptomeria japonica forest, $200 \mathrm{~m}, 7$ juv., 3 August 1990, NT. Yamaguchi City: Mt. Tokusagamine, 850-900 m, 1ㅈ1우, 3 July 2011, Susumu Kakinuma; Tokujinodani, Lake Ohara Forest for Birdwatching, 2ㅇ, 5 May 2012, Shin-ichi Tanaka; Mt. Shogen, Cryptomeria japonica forest, 520 m, 3 juv., 3 August 1990, NT. Shûnan City: Yuno, Tsuzumi-no-taki Falls, 176 m: 2 juv., 31 July 2011, Ayako Nishijima; 1 juv., 2 October 2011, Ayako Nishijima. Shimonoseki City: Toyota-cho, Sekichû-kei Gorge, Cryptomeria japonica forest, 180 m, 4 juv., 2 August 1990, NT.

Intermediate forms between 5-spined and 6-spined forms HIROSHIMA PREF.: Edajima City (Okimi-cho), Is. Nishi-Nômi, Takamatsu Pass, Cryptomeria japonica forest, 160 m, 1 juv., 17 July 1990, NT.

Six-spined form - HYOGO PREF. - Shisô City, Haga-cho, Tokura Pass, Cryptomeria japonica forest, 760 m, 3 juv., 12 August 1987, NT. TOTTORI PREF. - Yazu-gun, Wakasa-cho, Mt. Hyonosen, 23 (All Chrom), 12 September 2012, NT. Yazu-gun, Chizu-cho: Komagaeri Forest Road, 520 m, 10 24 May, 1992, Mari Murakami; Mt. Nagisan, Cryptomeria japonica forest, 620 m, 10, 16 September 1990, NT. Tottori City: Momodani, Momodani Shrine, Cryptomeria japonica forest, $70 \mathrm{~m}, 1$ 우, 14 March 1992, NT; Ochidani, 50 m, 1우, 27 May 1988, Noriko Makabe \& Kaori Morihara. Tottori City, Koyama, Campus of Tottori University: 1우, 17 April 1987, NT; Pinus densiflora and Phyllostachys heterocycla forest, 20 m, 1ㅇ, 13 October 1989, NT. Tottori City, Kawahara-cho: Gôbara, 1 juv., 26 August, 2010, Yachiyo Enginioring; Mitaki Gorge, 520-600 m, 1 juv., 22 August 1992, NT. Tottori City: Yahagi, Mt. Kenashi Cryptomeria japonica forest, $270 \mathrm{~m}, 10^{\Uparrow}, 27$ November 2011, NT; Shikano-cho, Mt. Jûbô, Obata Forest Trail, Cryptomeria japonica forest, $350 \mathrm{~m}, 10^{\pi}, 25$ April 1992, NT; same, $380 \mathrm{~m}, 10^{\pi}, 3$ June 1992, NT: Kôchi, Hondani, Hôshigadaki Falls, Cryptomeria japonica forest, $440 \mathrm{~m}, 10^{2}$, 5 September 2002, Hiroaki Todoroki \& Rokuzan Yamamoto, NT. Tottori City, Shikano-cho, from Kôchi to AoyaObata Forest Trail: Upper side of Nameri-ishi, Cryptomeria japonica forest, $360 \mathrm{~m}, 10^{\Uparrow}$, 5 September 2002, Hiroaki Todoroki \& Rokuzan Yamamoto, NT; Border between Aoya-cho and Shikano-cho, Cryptomeria japonica forest, 450 m, 2우, 5 September 2002, Hiroaki Todoroki \& Rokuzan Yamamoto, NT. Tottori City, Aoya-cho, Fudôsan, Yubara Falls, 1우, 21 September 1987, NT. Tôhaku-gun, Misasa-cho: Baba-no-taki Falls, Cryptomeria japonica forest, $240 \mathrm{~m}$, $2 \precsim 1$ 우, 3 September 1999, NT; Mt. Tsuguro, Ôtani Pass, bamboo field, 900 m, 3 33우1 juv., 22 September 1988, NT; Northeastern slope of Mt. Hotokegasen, Cryptomeria japonica forest, $570 \mathrm{~m}, 1$ 우, 22 September 1988, NT. Kurayoshi City, Sekigane-cho, Shimizu, Shimizu River (Right bank) Cryptomeria japonica forest, $310 \mathrm{~m}, 1$ juv., 23 August 1992, NT. Tôhaku-gun, Kotoura-cho, Akasaki-cho: Mt. Senjo, Starting Point for Climbing. Pinus densiflora forest, 400 m, 1§ 27 August 1987, NT; Ôkuma, Cryptomeria japonica forest, 140 m, 51우, 27 August 1987, NT. Daisen-cho: (Nakamaya-cho), Sekimi, Pinus densiflora and Chamaecyparis obtusa forest, $210 \mathrm{~m}, 1$ ð, 21 September 1987, NT. Daisen-cho, (Daisen-cho): NakaMakihara, Field Athletic Cryptomeria japonica forest, 340 m, 2 juv., 19 August 2005, NT, Kae Izawa, Shoko Okuda; Mt. Daisen, From Sama to Misaka, Cryptomeria japonica forest, $250 \mathrm{~m}, 1$ juv., 20 August 1992, Noriko Aoki \& NT. Saihaku-gun, Hoki-cho (Mizoguchi-cho): Udai, Cryptomeria japonica forest, $100 \mathrm{~m}, 1$ juv., 8 July 1990, NT; Yakura-dawa Pass, Cryptomeria japonica forest, 460 m, 1우, 9 September 1989, NT. Hino-gun, Kôfu-cho, Kagamiganaru, 940 m, $1{ }^{\rtimes} 1$ juv., 27 August 1987, NT. Hino-gun, Hino-cho, Mt. Hôbutsu, Forest Road from Kamochi, 460 m, 13, 16 September 1999,
NT. Hino-gun, Nichinan-cho: Mt. Hanami, Hanamiyama Skiing Ground, Cryptomeria japonica forest, 730 m, 10 25 April 1988, NT; Sugesawa, Sugesawa Shrine, 390 m, 1우, 30 September 2008, Toshihiko Matsuo; Sugesawa, Ômiya Dam, 400 m: $1{ }^{\Uparrow 1} 1$ juv., 7-8 July 2008, Toshihiko Matsuo; 1우, 30 September 2008, Toshihiko Matsuo; Sugesawa, East shore of Lake Nichinan, 400 m, 1子`2우, 7-8 July 2008, Toshihiko Matsuo. SHIMANE PREF. - Un-nan City, Kisuki-cho, Shakunouchi Park, 2우 4 October 2011, Masakazu Hayashi. Matsue City, Mt. Makuragi, Kezoji Temple, 400 m, 1ㅇ, 17 July 1988, NT. Ôda City, Torii-cho, Torii, 4 juv., 6 August 2011, K. Obara, Ôda City, Yusato, Mt. Yataki-jôzan, 170 m, 2 juv., 22 July 2006, NT. Hamada City, Misumi-cho, Mt. Ôasa, Orii River, Cryptomeria japonica forest, 30 m, 3 juv., 22 July 1990, NT. OKAYAMA PREF. - Tomata-gun, Kagamino-cho, Shiraka Gorge, 550 m, 2`1우, 20 November 2010, NT. Maniwa City, Yatsuka-son, Mitano, Cryptomeria japonica forest, 1 juv., 16 July 1991, NT. Ihara City, Yoshii-cho, Tenjin-kyo, Ten Shrine, Cryptomeria japonica forest, $90 \mathrm{~m}, 1 \mathrm{\delta}^{\curvearrowright} 1$ juv., 6 August 2000, NT. Maniwa-gun, Shinjo-son, Doyô Dam, Cryptomeria japonica forest, $680 \mathrm{~m}, 1$ juv., 27 July 1990, NT, HIROSHIMA PREF. Shobara City: Kakkake Pass, Cryptomeria japonica forest, 760 m, 2 ð, 21 May 1988, NT; Saijo-cho, A Pass between Hainiwa and Itane, Cryptomeria japonica forest, $700 \mathrm{~m}, 1$ 우, 4 October 1988, NT; Takano-cho, Ônuki-dawa Pass, Cryptomeria japonica forest, 630 m, 3 juv., 6 August 1990, NT. Yamagata-gun, Kita-Hiroshima-cho: (Ôasacho), A Pass between Otsuka and Mizuho, Cryptomeria japonica forest, 560 m, 1 juv., 5 August 1990, NT; (Chiyoda-cho), Niedani Pass, Cryptomeria japonica forest, $440 \mathrm{~m}, 1$ juv., 5 August 1990, NT. Yamagata-gun, Aki-ota-cho (Kake-cho), Kuro Pass, Cryptomeria japonica + Chamaecyparis obtusa forests, 330 m, 1 juv., 18 July 1990, NT. Hiroshima City, Asa-Minami Ward, Numata-cho, KamiOkuhata, Cryptomeria japonica forest, 340 m, 3 juv., 16 July 1990, NT. KAGAWA PREF. - Higashi-Kagawa City, Hoshigoe Pass, Pleioblastus simonii bamboo forest, $110 \mathrm{~m}, 1$ 우, 14 September 2008, NT. Sanuki City, Nagao-machi, Yuzuriha, 1우, 21 September 2002, Susumu Mitani. Nakatado-gun, Man-nô-cho (Kotonan-cho), Hachimine, 1ð, 14 September 2003, Susumu Mitani. EHIME PREF. - Matsuyama City: Is. Gogoshima, Tomari-cho, Kurosaki, $20^{\Uparrow} 1$ 우10 juv., 10 August 2000, NT; Tsuzurakawa, Mt. Kuromori, 530 m, $1 \jmath^{1} 1$ 우1 juv., 28 August 1999, NT. Kami-Ukena-gun, Kuma-kogen-cho: Omogo-mura, Nakayama to Tokoroyabu (near Omogo Dam), Cryptomeria japonica forest, 780 m, 1 juv., 24 August 1989, NT. Kuma-kôgen-cho, Mt. Saragamine, Ryujin-daira: Sasa bomboo, 1160 m, 2399우, 7 October 1983, NT; Fagus crenata forest, 1160 m, 1ठ, 13 June 2008, NT; Sasa bomboo grassland, 1150 m, 3 juv., 18 August, 2007, NT. Kita-gun, Uchiko-cho, Oda-miyama, Hondani: 1150 m, 2 ऽ1 juv., 7 August 1988, Eiji Yamamoto; Quercus acutissima forest, 4 §5우, 12-13 September 1994, Eiji Yamamoto; 1우, 8 October 1994, Eiji Yamamoto. Oda-miyama: Mt. Koyayama: 1300 m, 2 + 4 juv., 28 August 1988, Eiji Yamamoto; 10, 3 August 1994, Eiji Yamamoto; Namakusadani, 1우, 18 October 1994, Eiji Yamamoto; Myôken-nomori Forest Trail, Sasa bamboo grassland, 1090 m, 1우, 13 August 1996, NT; Fagus crenata forest, $1 \delta^{\Uparrow} 1$ 우2 juv., 5 August 1991, Eiji Yamamoto; Oda-miyama, SW of Mt. Amagiri, (Rokuro to Shishigoe Pass), Cryptomeria japonica forest, 910 m, 3 juv., 13 August 1996, NT. Uchiko-cho, Oda-miyama Gorge: 1우, 10 June 1994, Eiji Yamamoto; 20, 15 October 1995, Eiji Yamamoto; Oda-miyama Natural Forest, 800-900 m, 1ð̊, 7 June 1988, Eiji Yamamoto. Kitagun, Hijikawa-cho, Yamatosaka: 2우, 22-25 June 2004, Keiko Ueno et al.; 2 juv., 8-12 August 2004, Keiko Ueno et al. Higashi-Uwa-gun, Nomura-cho, Ohnogahara, Natural Beech Forest Parking, 1280 m, 3 juv., 14 August 1991, NT. Uwajima City, Mt. Yatsuzura, Fagus crenata forest, $1160 \mathrm{~m}, 1 \delta^{\Uparrow}, 22$ May 2000, NT. KAGOSHIMA PREF. - Mt. Kirishima, 1 juv., 10 August 1956, Teruo Irie.

Paraumbogrella pumilio (Karsch 1881) - Hokkaido Sunagawa City, on a levee of Penkeutashinai River: 3 주우, 16 October 1985, NT; 1ठㄱ, 6 November 1985, NT; 2우, 8 October 1986, NT. 
Ebetsu City, Nopporo, 1우, 11 September 1986, NT. Sapporo City: Tsukisamu, Hokkaido Agricultural Experiment Station, 23, 19-25 October 1986, Nobuyo Yoshida; Mt. Sankaku, 130 m, 1ㅇ, 28 April 1985, NT. Sapporo City, Campus of Hokkaido University: 15 13 우, 10 October 1982, NT; 7 35 우, 29 April 1984, NT; 2ð, 7 October 1984, NT; 8ㄱ1우1 juv., 23 September 1985, NT; 111우 (111ㅜㅇㅜ Chrom), 27 September 1985, NT; $27 \delta^{1} 8$ 우2 juv. (11주우1 juvenile female Chrom), 26 September 1986, NT. Tomakomai City, Tomakomai Forest Experiment Station of Hokkaido University, 1ð, 15 July 1983, NT. IBARAKI PREF. - Kuji-gun, Daigo-cho, Daigo, 3기우, 27 August 1985, Toshio Hayashi. SAITAMA PREF. - Toda City, Doman, grassland, 1우 13 November 1986, Kiyoshi Ishii. Tokorozawa City, Mikajima, Horinouchi, 2ㅇ, 15 September 1987, Nao Matsumoto. TOKYO PREF. - Nishitama-gun, Mizuho-cho, Mt. Komagata-Fujisan, 10, 9 January 1984, Susumu Nakano. KANAGAWA PREF. - Yokohama City: Kôhoku Ward, Kodukuecho, Riverbed of Tsurumi River, 4우, 28 March 1994, Yoshimasa Goto; Izumi Ward, Izumi-cho, 2子2우, 11 March 1995, Yoshimasa Goto; Tsurumi Ward, Shishigaya-cho, Shishigaya Shimin-no-mori Forest, 10 26 November 1994, Yoshimasa Goto. Hadano City, Lake Shinjô, 1ơ 10 January 1984, Jun-ichi Aoki. TOYAMA PREF. Toyama City, Furusawa, Family Park: 10, 16 September 1996, Yoshiko Hirauchi; 1우, 16 September 1996, Noboru Nunomura, 3 juv., 20 September 1996, Noboru Nunomura; 1ð, 6 December 1997, Noboru Nunomura. Toyama City: Yokogoshi, West bank of the rivermouth of Joganji River, 1ㅇ, 20 October 1978, Noboru Nunomura; Ômura: 10 4 June 1990, Noboru Nunomura; Pinus thunbergii forest, 1우, 11 July 1990, Noboru Nunomura; Hikatae, Pinus thunbergii forest, 1 juv., 11 July 1990, Noboru Nunomura; Hamakurosaki Beach, Pinus thunbergii forest, 10, 11 July 1990, Noboru Nunomura. ISHIKAWA PREF. - Wajima City, Kami-Osawa (West bank of Nishifutamata River), Nature trail along seashore, $10 \mathrm{~m}$ alt., $1{ }^{\jmath} 1$ 우, 23 August 1994, NT. Kanazawa City, Botanical Garden in the former Marunouchi Campus of Kanazawa University, 10, 9 October 1991, Ryoichi Ohgushi. AICHI PREF. - Okazaki City, Watari-machi, Riverbed of Yahagi River, 2ð, 7-19 May 1992, Toshiaki Murakami. SHIGA PREF. - Takashima City, Makino, Nishihama Moor, $1{ }^{\circledR} 1$ juv., 4 July 2009, Noboru Nunomura. TOTTORI PREF. - Tottori City. Riverbeds and Flood Channel of Sendai River, Riverbeds beneath Sendai-ôhashi Bridge: 2 m, 7ð2우, 17 May 1992; $1 \overbrace{}^{` 2}$ juv., 1 June 1992, NT; 12우, 3 March 1994, NT; 1 우, 13 August 2006, NT; $53^{7} 9$ 우, 18 October 2006, NT et al. Flood Channel of Sendai River: Furumi, between Sendai Bridge and Sendai-ohashi Bridge, Left bank, Phragmites communis community, 11 July 2006, NT et al.; Flood channel (Left bank) above Sendai-ôhashi Bridge, 2ð, 24 October 2012, Satoshi Kawato; Ezu, below Tottori-ohashi Bridge, Right bank, $1 \mathrm{~m}, 1$ 우, 25 October 2006; Sendaigawa Sports Square Parking, above Yachiyo Bridge, NT et al. Tottori City: Karo-cho, Karo Sand Dunes: Pinus thunbergii forest, $10 \mathrm{~m}: 1$ ㄱ2 2 우, 26 November 1991, NT; $1{ }^{2} 2$ 우, 26 November 1991, NT. Tottori City, Koyama-cho, Campus of Tottori University, Pinus densiflora + Phyllostachys heterocycla forest, 20 m, 1 juv., 30 June 1989, NT. Yonago City, Riverbeds of Hino River: Kaike-Shinden, rivermouth, 0 m, 4 $\mho^{1} 10$ 우3 juv, 28-30 July 2008, Toshihiko Matsuo; Kuzumo, near Kuzumo Weir, Phragmites communis community, 2 m, 5 ${ }^{7} 13$ 우32 juv., 28-30 September 2008, Toshihiko Matsuo; 1 juv., 2 October 2008, Toshihiko Matsuo. 